\title{
PENERAPAN TEKNOLOGI PENGOLAHAN LIMBAH KELAPA SEBAGAI PUPUK ORGANIK DAN NATA DE COCO
}

\author{
Darma Bakti, Ridwansyah dan Isman Nuriadi \\ Fakultas Pertanian Universitas Sumatera Utara \\ Email :dbakti06@yahoo.com
}

\begin{abstract}
Abstrak
Kegiatan pengabdian kepada masyarakat dilaksanakan oleh Tim Pengabdian kepada Masyarakat yang berjudul "Penerapan Teknologi Pengolahan Limbah Kelapa Sebagai Pupuk Organik dan Nata de Coco" merupakan kegiatan pengabdian dengan melibatkan dua mitra, yaitu Kelompok Tani Bakti Karya dan Kelompok Wanita Tani Mekar Jaya merupakan dua kelompok tani yang aktif dalam budidaya dan pengolahan kelapa di Desa Asahan Mati, Kecamatan Tanjung Balai Kabupaten Asahan. Permasalah yang dihadapi adalah rendahnya kuantitas dan kualitas produksi kelapa yang disebabkan oleh keterbatasan informasi mengenai kultur teknis budidaya kelapa terutama aspek pengendalian hama penyakit dan pemupukan. Selain itu keberadaan limbah jerami kelapa berupa pelepah dan daun serta air kelapa yang jumlahnya sangat besar menjadi permasalah tersendiri karena berpotensi menyebabkan terjadinya pencemaran lingkungan dan menjadi sarang hama. Untuk dapat memecahkan masalah ke dua Mitra tersebut, maka kegiatan ini dilaksanakan dalam bentuk ceramah, diskusi, praktek dan introduksi mesin pencacah limbah kelapa berupa daun dan pelepah untuk dijadikan bahan baku pupuk organik, introduksi bibit kelapa hibrida dan peralatan pengolahan limbah air kelapa untuk pembuatan nata de coco. Setelah pelaksanaan kegiatan pengabdian kepada masyarakat mitra telah mampu membuat membuat pupuk organik bokashi dengan memanfaatkan limbah tanaman kelapa dengan menggungkan mesin cacah yang diintroduksikan, praktek budidaya kelapa hibrida, dan pengolahan limbah air kelapa menjadi nata de coco. Hasil dari kegiatan ini dapat meningkatkan produksi kelapa hibrida sekaligus menjaga kelestarian lingkungan hidup.
\end{abstract}

Kata kunci: kelapa, limbah, pupuk organik, nata de coco

\begin{abstract}
Community service activities is one of the obligations that must be implemented by lecturer at the university sabagai one aspect of Tri Dharma Perguruan Tinggi. The activity was carried out by a Team of Community Service entitled "The Application of Coconut Waste Processing Technology as Organic Fertilizer and Nata de Coco" is a devotion activity involving two partners, namely Bakti Karya Farmer Group and Mekar Jaya Farmer Group are two groups of farmers who are active in cultivation and coconut cultivation in Desa Asahan Mati, Tanjung Balai Sub-district of Asahan Regency. Problems faced is the low quantity and quality of coconut production caused by the limited information about the culture culture of coconut cultivation, especially aspects of pest control and fertilization. In addition, the presence of coconut straw waste in the form of midrib and leaves and coconut water that is very large to be a problem because it has the potential to cause environmental pollution and become a pest of nests. . In order to solve the problems of both partners, this activity will be conducted in the form of lectures, discussions, practices and introduction of coconut chopping machine in the form of leaf and stem to be used as raw material of organic fertilizer, hybrid coconut seeds and coconut
\end{abstract}


waste water treatment equipment as nata de coco. After the implementation of the dedication activity to the partner community has been able to make organic fertilizer bokashi by utilizing the waste of coconut plants by digging the compost cutting machine that introduced, the practice of hybrid coconut cultivation, and waste water treatment of coconut to nata de coco. The results of these activities can increase hybrid coconut production while maintaining environmental sustainability,

Keywords: coconut, waste, organic fertilizer, nata de coco

\section{PENDAHULUAN}

Sektor pertanian merupakan sektor yang mempunyai peranan strategis dalam struktur pembangunan perekonomian nasional. Sektor pertanian memiliki peran yang strategis dalam pembangunan perekonomian nasional. Tidak saja sebagai penyedia bahan pangan, bahan baku industri, pakan dan bioenergi, penyerap tenaga kerja, sumber mata pencaharian dan sumber devisa negara, pertanian juga berperan sebagai pendorong pengembangan wilayah dan sekaligus pendorong pengembangan ekonomi kerakyatan. Berbagai peran strategis tersebut sejalan dengan tujuan pembangunan perekonomian nasional yaitu meningkatkan kesejahteraan masyarakat Indonesia, mempercepat pertumbuhan

ekonomi, mengurangi kemiskinan, menyediakan lapangan kerja, serta memelihara keseimbangan sumberdaya alam dan lingkungan hidup.

Perkebunan merupakan salah satu komoditas yang bisa diandalkan sebagai sentra bisnis yang menggiurkan. Terlebih produkproduk tanaman perkebunan cukup ramai permintaannya, baik di pasar dalam negeri maupun pasar luar negeri. Selain itu, harga jual yang tinggi juga membuat tanaman perkebunan menjadi salah satu penyumbang devisa negara yang tidak sedikit. Kelapa merupakan tanaman perkebunan dengan areal terluas di Indonesia, lebih luas dibanding karet dan kelapa sawit, dan menempati urutan teratas untuk tanaman budidaya setelah padi. Pada tahun 2008 Indonesia dikenal memiliki luas perkebunan kelapa terbesar di dunia yakni 3.798 ribu Ha, sebagian besar merupakan perkebunan rakyat seluas 3,729 ribu ha $(98,18 \%)$ sisanya milik negara seluas 5,5 ribu ha $(0,14 \%)$ dan perkebunan milik swasta seluas 64 ribu ha (1,68\%), dengan total produksi sebesar 2.247 ribu ton setara kopra (Direktorat Jendral Perkebunan, 2009).

Kabupaten Asahan merupakan sentra produksi kelapa terbesar di Sumatera Utara. Kabupaten Asahan Salah satu kecamatan di kabupaten Asahan yang memiliki potensi perkebunan kelapa adalah Kecamatan Tanjung Balai. Hal ini ditunjukkan dengan jumlah produksi yang tinggi pada tahun 2011 yaitu sebesar 8.428,50 ton dengan luas tanam seluas 5.869 ha. Produktivitas tanaman kelapa baru mencapai 2.700-4.500 kelapa butir yang setara 0,8-1,2 ton kopra/ha. Produktivitas ini masih dapat ditingkatkan menjadi 6.750 butir atau setara 1,5 ton kopra. Hal ini dapat dilakukan dengan pemeliharaan semi intensif terhadap pertanaman kelapa, mengingat kondisi pertanaman kelapa saat ini sudah tua dan rusak sehingga perlu dilakukan peremajaan dan rehabilitasi (Deptan, 2007). Permasalahan yang dihadapi mitra pada kegiatan ini adalah produksi kelapa yang masih rendah dan penumpukan limbah tanaman kelapa seperti pelepah daun kelapa dan air kelapa yang belum dapat dimanfaatkan sehingga berpotensi mencemari lingkungan dan menjadi sarang hama.

Potensi sumberdaya kelapa sebenarnya sangat besar dan memungkinkan untuk pengembangan suatu agribisnis yang kuat, dengan struktur agroindustri yang saling terkait dari hulu hingga ke hilir. Menurut Alleorung (1998), salah satu usaha untuk meningkatkan pendapatan petani kelapa adalah dengan 
mengolah semua komponen buah menjadi produk yang bernilai tinggi, sehingga nilai buah kelapa akan meningkat, termasuk pemanfaatan limbah kelapa yang selama ini belum dimanfaatkan, tidak memiliki nilai ekonomis dan berpotensi mencemari lingkungan.

Upaya yang ditawarkan oleh tim
pengusul kegiatan pengabdian kepada masyarakat adalah pembuatan pupuk organik bokashi berbahan baku limbah kelapa. Bokashi merupakan pupuk organik padat yang dalam proses pengomposannya melalui proses fermentasi dan memanfaatkan mikroorganisme efektif. Manfaat bokashi antara lain adalah menggemburkan tanah, menghasilkan unsur hara makro dan mikro yang dapat diserap perakaran tanaman, dan merangsang pertumbuhan tanaman (Indriani, 2005). Pupuk bokashi yang dihasilkan dapat diaplikasikan pada areal pertanaman kelapa atau tanaman pangan lainnya serta dapat dijual untuk menambah penghasilan petani. Untuk mempermudah pembuatan pupuk organik bokashi, bahan baku berupa pelepah dan daun kelapa dicacah dengan menggunakan mesin pencacah yang akan diintroduksikan pada kegiatan ini.

Sedangkan upaya pemanfaatan limbah air kelapa pada proses pengolahan kopra adalah dengan membuat nata de coco berbahan baku air kelapa. Pembuatan nata de coco berbahan baku limbah air kelapa diharapkan dapat menambah penghasilan bagi anggota Kelompok Wanita Tani Mekar Jaya serta sebagai bahan alternatif diversifikasi produk pangan untuk meningkatkan gizi keluarga. Nata de coco merupakan sebuah inovasi fermentasi untuk memanfaatkan limbah air kelapa yang cukup melimpah yang jarang dimanfaatkan oleh banyak orang. Limbah air kelapa biasanya dibung begitu saja dan hanya diambil buahnya saja, bahan baku pembuatan nata de coco yaitu limbah air kelapa dapat diperoleh dengan harga yang murah bahkan gratis tetapi setelah diolah menjadi nata de coco dapat menghasilkan profit yang cukup baik. Nata de coco merupakan produk hasil fermentasi air kelapa dengan bantuan aktivitas bakteri Acetobacter xylinum. Nata berasal dari bahasa Spanyol yang artinya terapung. Ini sesuai dengan sifatnya yaitu sejak diamati dari proses awal terbentuknya nata merupakan satu lapisan tipis yang terapung pada permukaan yang semakin lama akan semakin tebal (Saputra, 2009).

Nata de coco merupakan produk yang memiliki kadar serat tinggi. Serat yang terkandung dalam nata meliputi selulosa, hemiselulosa, lignin, dan serat larut air. Sehingga dengan keunggulan pada kandungan seratnya tersebut, maka nata de coco dapat mencegah dan meminimaalkan terjadinya beberapa macam penyakit. Manfaat dari nata de coco adalah sebagai penurun kolesterol, glukosa darah pada penderita diabetes mellitus, mencegah konstipasi, mengendalikan berat badan (mencegah obesitas), mencegah kanker kolon, dan bermanfaat pada mikroflora di usus besar. Nata de coco merupakan makanan kesehatan yang kaya serat, tetapi rendah kalori. Nata de coco mengandung air sekitar 98\%, lemak $0.2 \%$, kalsium $0.012 \%$, fosfor $0.002 \%$, dan vitamin B3 0.0017\% (Nurheni et al., 1990). Hasil dari penelitian menunjukkan bahwa serat dalam makanan ini dapat digunakan untuk penurunan kolesterol dan mengurangi resiko penyakit kanker.

\section{METODE}

Metode pendekatan yang akan dilakukan untuk mendukung realisasi kegiatan pengabdian kepada masyarakat pada mitra yaitu ceramah dan diskusi, pelatihan disertai praktek pembuatan pupuk organik bokashi dari limbah tanaman kelapa, budiaya kelapa hibrida dengan mengaplikasikan pupuk organik bokashi dan pengolahan limbah air kelapa menjadi nata de coco.

Metode yang digunakan dalam program ini dalam bentuk :

a. Ceramah dan diskusi tentang prospek dan cara budidaya kelapa hibrida.

b. Pelatihan pembuatan pupuk organik organik bokashi dengan menggunakan mesin pencacah kompos

c. Pelatihan teknik budidaya kelapa hibrida dengan mengintroduksi bibit kelapa hibrida berkualitas. 
d. Pelatihan pengaplikasian pupuk organik bokashi pada pembibitan dan budidaya kelapa hibrida. e. Pelatihan pembuatan nata de coco dengan memanfaatkan limbah air kelapa.

Tabel 1. Rancangan Evaluasi Pengabdian Masyarakat Mono Tahun Non-PNBP USU

\begin{tabular}{|l|l|l|}
\hline \multicolumn{1}{|c|}{ Kriteria } & \multicolumn{1}{|c|}{ Indikator Pencapaian Tujuan } & \multicolumn{1}{c|}{ Tolok Ukur } \\
\hline $\begin{array}{l}\text { Pembuatan pupuk } \\
\text { organik bokashi dari } \\
\text { limbah pelepah dan } \\
\text { daun kelapa }\end{array}$ & $\begin{array}{l}\text { Pemahaman anggota kelompok } \\
\text { tani dan praktek untuk membuat } \\
\text { pupuk bokashi dari limbah pelepah } \\
\text { dan daun kelapa }\end{array}$ & $\begin{array}{l}\text { Anggota kelompok tani memahami dan } \\
\text { mampu untuk membuat pupuk organik } \\
\text { bokashi dari pelepah dan daun kelapa } \\
\text { dengan menggunakan mesin pencacah. }\end{array}$ \\
\hline Budiaya kelapa & $\begin{array}{l}\text { Pemahaman anggota kelompok } \\
\text { tani dan praktek budidaya kelapa } \\
\text { terutama pengendalian hama } \\
\text { penyakit dan pemupukan }\end{array}$ & $\begin{array}{l}\text { Anggota kelompok tani memahami } \\
\text { budidaya kelapa dan terdapat peningkatan } \\
\text { produksi kelapa atau tanaman pangan } \\
\text { lainnya sebesar 20\%. }\end{array}$ \\
\hline $\begin{array}{l}\text { Teknik panen dan } \\
\text { pascapanen kelapa }\end{array}$ & $\begin{array}{l}\text { Pemahaman anggota kelompok } \\
\text { tani untuk kriteria panen dan } \\
\text { penangangan pasca panen kelapa }\end{array}$ & $\begin{array}{l}\text { Kualitas dan harga jual kelapa dan produk } \\
\text { olahan yang dihasilkan dapat meningkat } \\
\text { dan sesuai dengan permintaan pasar }\end{array}$ \\
\hline $\begin{array}{l}\text { Pengolahan produk } \\
\text { pangan berbahan } \\
\text { baku limbah air } \\
\text { kelapa }\end{array}$ & $\begin{array}{l}\text { Pemahaman anggota kelompok } \\
\text { tani dan keluarganya mengenai } \\
\text { cara pembuatan nata de coco }\end{array}$ & $\begin{array}{l}\text { Anggota kelompok tani mampu membuat } \\
\text { berbagai produk pangan bergizi dan } \\
\text { bernilai ekonomis berbahan baku air } \\
\text { kelapa. }\end{array}$ \\
\hline
\end{tabular}

Kegiatan yang dilakukan yaitu pembuatan pupuk organik bokashi, praktek budidaya kelapa hibrida dan pengolahan limbah air kelapa menjadi nata de coco. Kegiatan ini memerlukan partisipasi aktif dari kedua belah pihak. Pihak Perguruan Tinggi (USU) harus berperan aktif dalam memberdayakan kelompok tani dengan melakukan proses alih teknologi dari kalangan Perguruan Tinggi ke petani. Demikian juga, kelompok tani harus berperan aktif untuk terselenggaranya pengabdian kepada masyarakat dalam menyediakan sarana tempat pelatihan. Untuk kegiatan pembuatan pupuk organik bokashi kelompok tani berpartisipasi dalam mengumpulkan limbah tanaman kelapa berupa daun dan pelepah kelapa, limbah hijauan dan kotoran ternak. Kelompok tani diharapkan memiliki sikap antusiasme tinggi untuk keberhasilan setiap tahapan kegiatan yang dilaksanakan. Kerja sama yang erat dan partisipasi aktif dari tim pelaksana kegiatan pengabdian masyarakat Perguruan Tinggi (USU) dan kelompok tani merupakan kunci yang menentukan keberhasilan program pengabdian pada masyarakat.

Pasca kegiatan dilaksanakan maka tim pelaksana dan kelompok tani melakukan evaluasi kegiatan guna mengukur keberhasilan kegiatan yang telah dilakukan. Rancangan evaluasi kegiatan, langkah-langkah dan indikator yang digunakan dalam rancangan evaluasi tersaji pada Tabel 1.

\section{HASIL DAN PEMBAHASAN}

Dari pelatihan pembuatan pupuk organik bokashi dengan memanfaatkan limbah tanaman kelapa yaitu daun dan pelepah kelapa terungkap bahwa sebagian besar anggota kelompok tani belum mengetahui cara pembuatan pupuk organik bokashi sehingga mereka sangat antusias dalam mengikuti pelatihan dan aktif berdiskusi mengenai teknik pembuatan pupuk organik bokashi.

Hasil kegiatan yang telah berhasil dilakukan adalah pembuatan pupuk organik bokashi dengan memanfaatkan limbah tanaman 
kelapa dengan menggunakan mesin pencacah. Introduksi peralatan tersebut akan mempermudah dan mempersingkat waktu bagi petani dalam mempersiapkan pupuk organik. Selain itu tim pelaksana juga menyampaikan teknologi pengomposan dengan menggunakan mikroba yang membantu mempercepat roses dekomposisi bahan organik yaitu EM4.

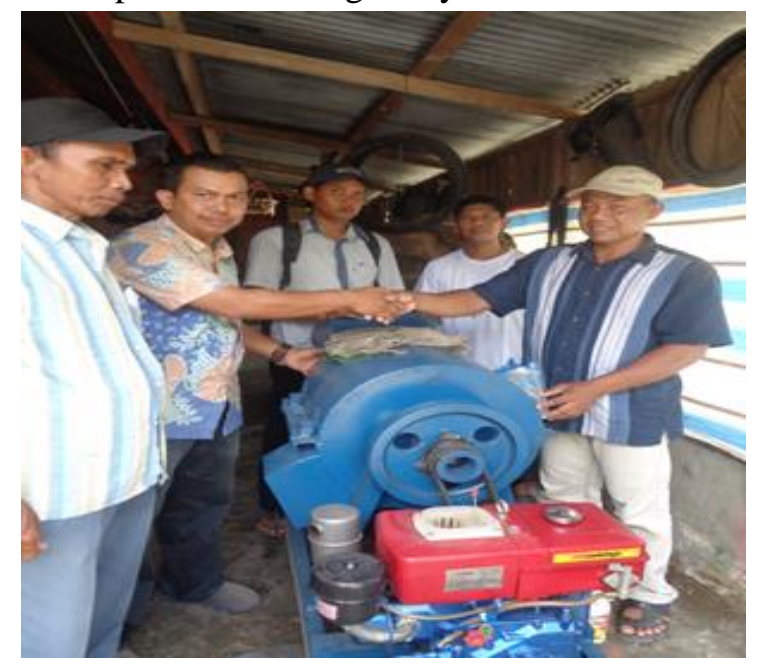

Gambar 1. Serah terima mesin pencacah

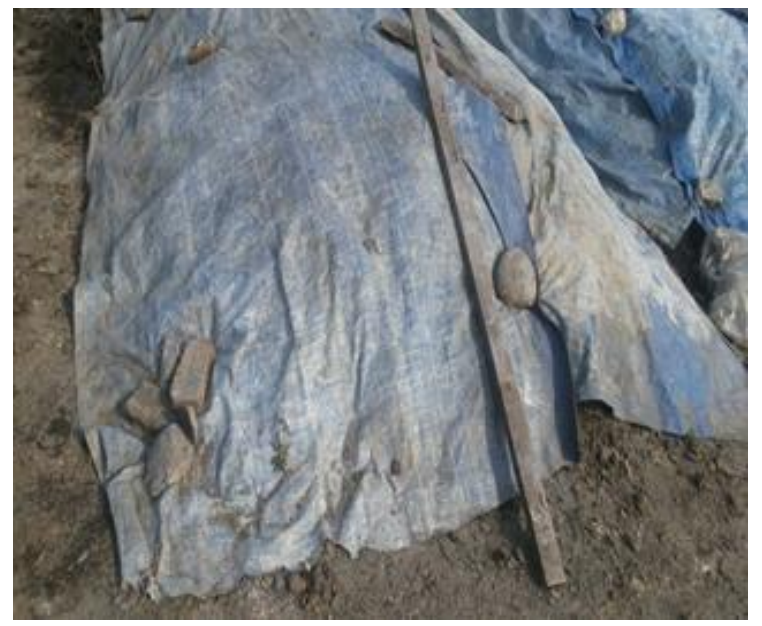

Gambar 2. Proses pembuatan pupuk organik bokashi

Lactobacillus yang terkandung dalam bokashi mampu melarutkan ion fosfat dengan bantuan asam laktat yang dihasilkan. Demikian juga dengan unsur lainnya seperti nitrogen dan kalium dari bahan organik yang dengan bantua mikroorganisme effektif dapat diuraikan menjadi bentuk-bentuk yang lebih sederhana, sehingga tanaman segera memanfaatkan unsur-unsur tersebut dan didapatkan tanaman yang lebih baik (Wididana, 1998).

Mikroorganisme efektif dalam bokashi mampu merangsang pertumbuhan mikroorganisme tanah yang menguntungkan misalnya Mycorhiza, Rhizobium, bakteri pelarut fosfat, dan lain-lain. Sehingga lebih banyak unsur hara yang mampu disediakan. Hasil dekomposisi sendiri selain menghasilkan unsur-unsur tersedia bagi tanaman, juga menghasilkan senyawa organik yang dapat mengikat ion-ion yang berada dalam kondisi stabil (antioksidan) yang dibutuhkan tanaman (Higa dan Wididana, 1996). Pengaruh menguntungkan dari serapan ini adalah turut diserapnya beberapa zat tumbuh dan vitamin yang dapat merangsang pertumbuhan tanaman (Soepardi,1983). Dalam pelaksanaan kegiatan pengabdian masyarakat ini, pupuk organik bokashi diaplikasikan pada budidaya kelapa yaitu pada bibit kelapa hibrida dan pada saat penanaman kelapa hibrida ke lapangan. Aplikasi pupuk organik bokashi dilakukan $2-4$ minggu sebelum pindah tanam dengan dosis $20 \mathrm{~kg}$ per lubang tanam. Aplikasi pupuk organik pada budidaya kelapa hibrida dapat meningkatkan pertumbuhan akar terutama bila tekstur tanah sedikti keras. Selain itu pupuk organik bokashi juga mampu menyerap lebih banyak air sehingga ketersediaan air di lingkungan rizosfer kelapa lebih terjaga terutama jika kelapa hibrida dibudidayakan pada areal dengan kandungan pasir yang tinggi.

Sebagai bahan praktek aplikasi pupuk organik bokashi pada budidaya kelapa hibrida, tim pelaksana kegiatan pengabdian kepada masyarakat telah menyerahkan 100 buah bibit kelapa hibrida. Keunggulan kelapa hibrida adalah :

a. Lebih cepat berbuah, sekitar $3-4$ tahun setelah tanam

b. Produksi kopra tinggi, sekitar $6-7$ ton/ha/tahun pada umur 10 tahun

c. Produktivitas sekitar 140 butir/pohon/tahun 
d. Daging tebal, keras dan kandungan minyak tinggi

e. Produktivitas tandan buah sekitar 12 tandan dan berisi sekitar 10 - 20 butir buah kelapa, daging buahnya mempunyai ketebalan sekitar $1,5 \mathrm{~cm}$.

Pupuk organik bokashi juga dapat diaplikasikan pada berbagai tanaman pangan seperti padi, keledai, jagung, dan berbagai jenis sayursayuran. Penggunaan pupuk organik bokashi dapat mengurangi penggunaan pupuk kimia sehingga biaya produksi dapat ditekan dan produksi hasil pangan yang dihasilkan lebih sehat.

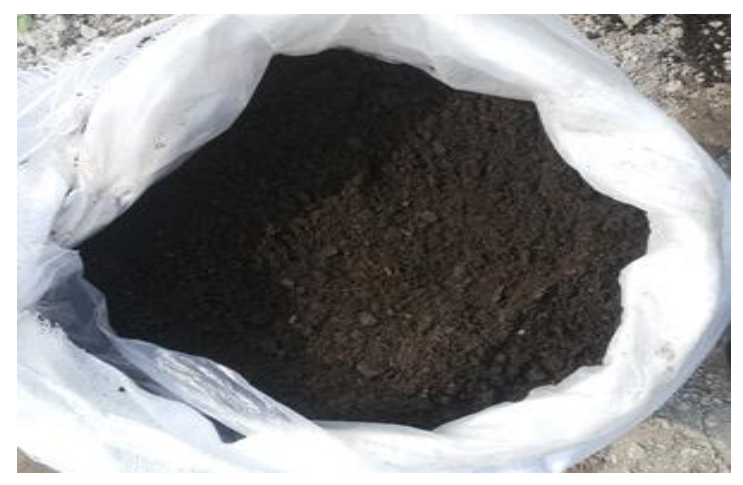

Gambar 3. Pupuk organik bokashi

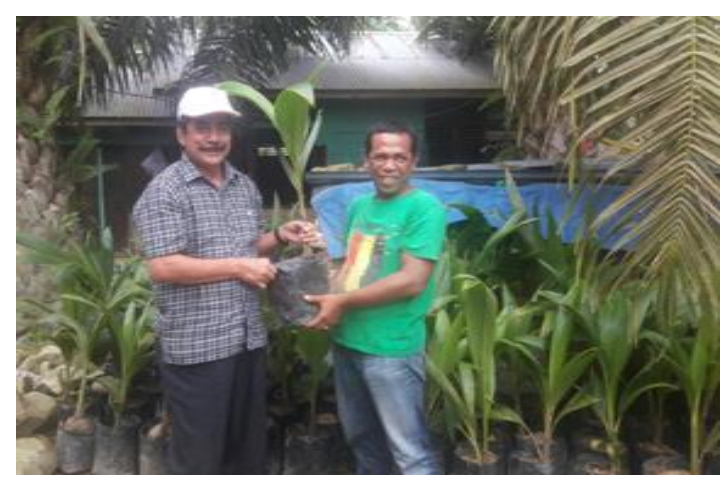

Gambar 4. Serah terima bibit kelapa hibrida Kepada mitra
Kegiatan tahap selanjutnya adalah pembuatan nata de coco dengan memanfaatkan limbah air kelapa. Nata de coco merupakan hasil proses fermentasi air kelapa dengan bantuan aktivitas Acetobacter xylinum. Nata berasal dari bahasa Spanyol yang artinya terapung. Ini sesuai dengan sifatnya yaitu sejak diamati dari proses awal terbentuknya nata merupakan suatu lapisan tipis yang terapung pada permukaan yang semakin lama akan semakin tebal (Saputra, 2009). Seperti halnya pembuatan beberapa makanan atau minuman hasil fermentasi, pembuatan nata memerlukan bibit yang disebut stater. Bibit nata de coco merupakan suspensi sel Acetobacter xylinum (Anonim, 2008).

Secara umum, air kelapa, mengandung $4,7 \%$ total padatan, $2,6 \%$ gula, $0,55 \%$ protein, $0,74 \%$ lemak, serta $0,46 \%$ mineral. Komposisi gizi yang demikian bagus menyebabkan air kelapa dapat digunakan sebagai media pertumbuhan mikroba, misalnya Acetobacter xylinum untuk produksi nata de coco. Buah kelapa yang sudah tua mengandung kalori yang tinggi, sebesar 359 kal per 100 gram, daging kelapa setengah tua mengandung kalori $180 \mathrm{kal}$ per 100 gram, dan daging kelapa muda mengandung kalori sebesar 68 kal per 100 gram. Sedang nilai kalori rata-rata yang terdapat pada air kelapa berkisar 17 kalori per 100 gram. Air kelapa hijau, dibandingkan dengan jenis kelapa lain banyak mengandung tanin atau antidotum (anti racun) yang paling tinggi. Kandungan zat kimia lain yang menonjol yaitu berupa enzim yang mampu mengurai sifat racun. 


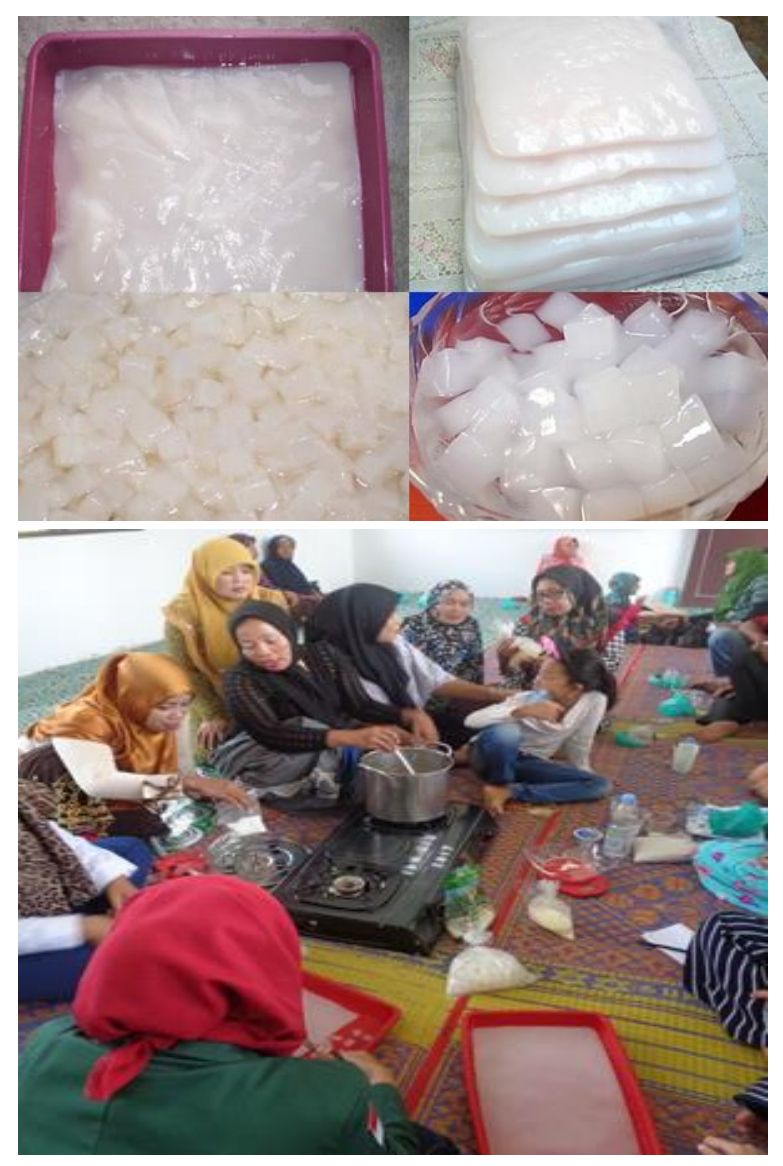

Gambar 5. Proses pembuatan nata de coco dari limbah air kelapa

Berdasar kajian Pusat Penelitian dan Pengembangan Biologi Lembaga Ilmu Pengetahuan Indonesia (Puslitbang Biologi LIPI), tiap 100 gram nata de coco terdiri dari 20 gram karbohidrat,20 gram lemak, 146 kalori, 2 miligram phospor, 0,5 gram zat besi, $12 \mathrm{mg}$ kalsium, dan 80 persen air. Nata de coco bukan hanya rasanya yang menyegarkan namun juga bermanfaat bagi tubuh. Kondisi nata de coco yang miskin nutrisi atau rendah kandungan gizi, membuat nata de coco sangat cocok dikonsumsi para penderita obesitas atau yang tengah melakukan diet rendah kalori, kadar serat yang dimiliki nata de coco mampu mengikat air dan menyerap karbohidrat dengan baik dan memperbesar proses penyerapan glukosa dalam tubuh.

Dengan banyaknya kandungan serat yang terdapat di dalam nata de coco, maka nata de coco dapat memperlancar pencernaan dan membantu menghindari sembelit atau konstipasi, wasir, radang usus buntu, kanker usus, diabetes, penyakit jantung koroner, dan membantu memperlancar buang air besar.

Mitra mengikuti kegiatan pembuatan nata de coco air kelapa dengan antusias karena Selama ini air kelapa yang banyak dihasilkan sebagai limbah pada pengolahan kopra belum memiliki nilai ekonomis. Dengan adanya transfer teknologi dari perguruan tinggi kepada mitra akan membuka peluang pemanfaatan air kelapa sebagai bahan baku pembuatan air kelapa yang bergizi tinggi. Nata de coco air kelapa yang dihasilkan dapat dikonsumsi langsung oleh anggota keluarga sehingga dapat meningkatkan status gizi. Selain itu produksi nata de coco air kelapa berpeluang untuk dipasarkan di daerah sekitar lokasi dan diharapkan dapat menambah penghasilan keluarga.

\section{KESIMPULAN}

1. Kegiatan pengabdian masyarakat yang telah dilakukan tim pelaksana dari Fakultas Pertanian USU memberikan manfaat kepada mitra dalam pemanfaatan limbah kelapa menjadi pupuk organik bokashi dan nata de coco.

2. Mitra telah mampu membuat pupuk organik bokashi berbahan limbah dedaunan dan pelepah daun kelapa yang pada awalnya tidak bernilai ekonomis dengan menggunakan mesin pencacah sehingga dapat mengurangi dampak pencemaran yang diakibatkan berlimpahnya limbah tersebut.

3. Mitra memahami dan mampu mempraktekkan aplikasi pupuk organik bokashi pada budidaya kelapa hibrida.

4. Mitra memahami dan mampu membuat nata de coco dari limbah air kelapa sehingga diperoleh nata de coco air kelapa yang bergizi dan mempunyai rasa yang enak.

\section{UCAPAN TERIMA KASIH}

Penulis mengucapkan terima kasih yang sebesar-besarnya kepada Universitas Sumatera Utara, Lembaga Pengabdian Pada Masyarakat 
Darma Bakti. et al. Penerapan Teknologi Pengolahan Limbah Kelapa Sebagai Pupuk Organik Dan Nata De Coco

(LPPM) USU, dan Kelompok Tani Bakti Karya dan Kelompok Wanita Tani Mekar Jaya Kabupaten Asahan yang telah memberi dukungan hingga terlaksananya kegiatan Pengabdian Masyarakat Mono Tahun Dana Non PNBP USU 2017 dengan Surat Perjanjian Penugasan Pelaksanaan Pengabdian kepada Masyarakat Nomor 3221/UN5.2.3.2.1/PPM/2017, Tanggal 24 Juli 2017.

\section{DAFTAR PUSTAKA}

Badan Pusat Statistik. 2014. Produksi Pertanian Sumatera Utara. Medan.

Barlina, R. 2007. Teknologi Pascapanen Kelapa Kopyor. Didalam: Novarianto $\mathrm{H}$, Monograf Kelapa Kopyor. Balai Penelitian Tanaman Kelapa dan Palma Lain, Manado.
BPTP, 2012. Produksi Pertanian Sumatera Utara, Medan

Indriani, Y.H. 2005. Membuat Kompos Secara Kilat. Penebar Swadaya. Jakarta.

Novarianto , H. 2005. Plasma Nutfah dan Pemuliaan Kelapa. Balai Penelitian Tanaman Kelapa dan Palma Lain, Manado.

Saputra, Y. E. (2009). Daya Tarik Nata de Coco Produk Kaya Serat. http://www.chem-istry.org

Soegito, S. Yulia, N. Ellis, N. 1995. Sistem Pertanian Organik. Fakultas pertanian Universitas Brawijaya. Malang, 84 hal

Wididana, G.N. 1998. Bokashi dan Fermentasi, Apa sih? Seri Informasi Teknologi EM. 